\title{
EFL Syllabus Design: Challenges of Implementation in Burkina Faso
}

\author{
Esther Somé-Guiébré ${ }^{1}$ \\ ${ }^{1}$ Ecole Normale Superieure, Université Norbert Zongo, Burkina Faso \\ Correspondence: Esther Somé-Guiébré, Ecole Normale Superieure, Universite Norbert Zongo, BP 34 Saaba 01, \\ Burkina Faso. Tel: 226-68-09-4885. E-mail: someesther@gmail.com
}

Received: December 19, 2017

doi:10.5539/ies.v11n6p73

\author{
Accepted: January 29, $2018 \quad$ Online Published: May 29, 2018 \\ URL: https://doi.org/10.5539/ies.v11n6p73
}

\begin{abstract}
The widespread use of English in the social, political, economic, and international business spheres compels non-English speaking countries to revise their English language curricula to meet the needs of the global economy. In Burkina Faso, educational policy makers have revised the English as a foreign language (EFL) syllabi from middle to high school with the expectation of helping students achieve communicative competence. However, the delayed implementation of these new syllabi unveils a discomfort from the perspective of both teachers and teacher supervisors. This paper provides a critique of the syllabi of quatrième (4ème) - the US equivalent of $8^{\text {th }}$ grades. It draws from document analysis and stakeholder interviews to highlight the discrepancies between the theory of the vision and the reality of the practice and assess the extent to which the syllabus promotes or hinders communicative competence. The overreaching argument is that despite tremendous efforts invested in the conception of syllabi, these tools hardly help implement communicative language teaching (CLT) in their classrooms.
\end{abstract}

Keywords: communicative language teaching (CLT), communicative competence, English as a foreign language (EFL), syllabi

\section{Introduction}

The teaching of English as a foreign language has taken several perspectives over time including the grammar translation approach and the audio-lingual approach. In the manner of other countries, those approaches have been used in the teaching of EFL in Burkina Faso and have revealed their limitations with regards to helping students develop a communicative competence in the language. That goal of achieving communicative competence in EFL has motivated policy makers to adopt communicative approach to language teaching (CLT) in the 1980s. However, the implementation of the communicative approach has been very slow in taking roots in the classroom as most teachers and, even, teacher education programs lay too weak an emphasis on CLT. Grammar translation methods and audio-lingual methods still take up much space in teacher education coursework. As a matter of fact, the English didactic coursework in 2012-2013 devoted 8 hours on Grammar translation methods and 8 hours on audio-lingual methods while CLT only took up 4 hours. Despite the very limited time budget allocated to CLT in their coursework, teachers are still expected to use methodologies that will promote communicative competence in the classroom. This paper examines the syllabi which have supposedly shifted from grammar-focused to communicative objectives and are currently used in Burkina Faso EFL classes, and investigates the extent to which the syllabi in Burkina Faso promote or hinder communicative competence. The paper lays a special focus on the syllabus used in Quatrieme (4ème), the equivalent of $8^{\text {th }}$ grade in the United States.

\section{Communicative Language Teaching: An overview}

In Burkina Faso, the goal of English language teaching, as officially stated in 1983, is to achieve communicative competence. According to Kramsch (2006), Communicative competence was introduced in the late 1970s in English as a foreign language teaching after it was initiated by Hymes in 1972. The notion of communicative competence has however taken different perspectives in the literature with scholars defining competence differently (Celce-Murcia, Dornyei, \& Thurrell, 1995). In this analysis, I am interested in the view of communicative competence as composed of grammatical competence, sociolinguistic competence, and communicative strategies (Canale \& Swain, 1980). All these components have shaped communicative language teaching which focuses on the "elaboration and implementation of programs and methodologies that promote the development of functional language ability through learner participation in communicative events" (Savignon, 
2007, p. 209). Along the same lines, Richard (2006) defines communicative language teaching as "a set of principles about the goals of language teaching, how learners learn a language, the kinds of classroom activities that best facilitate learning, and the roles of teachers and learners in the classroom" (p.2). In Savignon's (2002) perspective, it is concerned with the processes and the goals of classroom language learning and is based on the identification of learners' communicative needs.

In the same vein, the identification of learners' communicative needs constitutes the basis for classroom syllabus design which is defined by Yalden (1984) as an instrument used by teachers to achieve a "degree of fit between the needs and the aims of the learner [...] and the activities which will take place in the classroom" (p. 14). In his discussion about syllabus design, Nunan (1988) discusses two views of the word syllabus. The narrow view makes a distinction between syllabus design which is concerned with the "selection and grading of content" and methodology concerned with "learning tasks and activities" (p. 5). As for the broader view of the syllabus, it refutes the separation between syllabus design and methodology. This latter view of the syllabus is rooted in communicative language teaching, which "pays a systematic attention to functional as well as structural aspects of language" (Littlewood, 1982, p. 1).

In a similar vein, Richard (2013) notes that language teaching curricula involve content, process, and output. He identifies three approaches to language syllabus design that are "forward design" "central design" and "backward design." The choice of either one of those approaches is determined by the focus of the syllabus. In forward design for instance, the syllabus is centered on the language and the content is divided into key element while the methodology is transmissive, and teacher directed; central design is however activity based, the content is negotiated by learners, and the methodology is learner centered; as for the backward design, the syllabus is based on the needs of the learners and the methodology includes the practice of part-skills and real-life situations.

The literature has also discussed different types of syllabi that include the structural syllabus (Ellis, 1993), notional syllabus (Hurst, 1976), topic based syllabus (Bourke, 2006), situational syllabus, task-based syllabus, skill-based syllabus (Rahimpour, 2010). Nunan (1988) organizes those types of syllabi into two groups, product oriented and process oriented syllabi. If product oriented syllabi (grammatical syllabi and functional/notional syllabi) focus on "the end products or results of the teaching learning process," process oriented syllabi (procedural syllabi, task based syllabi, and content syllabi) are concerned with the process through which "knowledge and skills might be gained" (p. 40). A similar categorization of syllabi is made by Hadley (1998) who categorizes them as synthetic syllabi and analytic syllabi. Synthetic syllabi (structural, notional, functional, situational and topical syllabi) deal with what should be learned in second language classroom and the different parts of the language are taught separately. They rely on the belief that "a focus on accuracy will lead to fluency" (p. 57). Analytic syllabi, on the other hand (procedural, task based, and process syllabi) take "the concerns of the learners into deeper consideration and seem more focused on the business of learning rather than teaching.

The diversity of types of syllabi displays the need for the syllabus designer to determine the purpose of language teaching which according to Richard (2006) can be identified either to the traditional approach (up to the late 1960s), the classic communicative language teaching approach (1970s to 1990s), or the new communicative language teaching approach (1990s to present). He argues that the traditional approach focuses on deductive approaches to teaching grammar rather than inductive ones and uses the three Ps (presentation, practice and production) as a model for language teaching. However, proponents of CLT, who associate this model with grammar-based methodologies, have criticized and discarded it while advocating for functional and skill based teaching based on interactive group work.

\section{Methods}

\subsection{Study Site and Participants}

The study involves in/pre-service teachers of English as a foreign language in Burkina Faso. The participants were diverse in their teaching experience, their gender, and their motivations. They all graduated from national academic institutions and already attended or are attending teacher training. The level of education for secondary school teachers varies in Burkina Faso. Some teachers take the teaching training admission test after two successful years of college-and earning the equivalent of an associate degree in the U.S. Academic system. This category of teachers is trained to teach classes of middle school only, the equivalent of 6th through 9th grade in the U.S. Another group of teachers are eligible to take the teacher education school admission test after they have earned the bachelor's degree. The teachers in this category are equipped to teach English from 6th through 12th grade. Once the student has taken and passed the admission test, he/she attends the sole National Secondary teacher education school for a two-year training; the first year is meant for the theoretical training, while the second year is used to implement the acquisitions in the field. Upon a minimum of five years of successful teaching 
evidenced by grades given by the teacher supervisors, the first category of teachers (two years of college plus teacher training) can take another test for additional professional training at the teacher education school, after which they are eligible to teach students from grade 6th through 12th. There is also a third wave of teachers who do not go through formal training. They are often hired after two years of college or the bachelor's degree and sent directly to the classroom where they are expected to learn how to teach through their own teaching practices.

The in-service teachers involved in this study hold a teaching certificate and have been teaching for two to five years after their degree. They all teach in both middle and high school. As for the pre-service teachers, although they were still working towards their teaching certificates, most of them had at least two years experiences of teaching in private schools without prior training. Finally, the teachers in professional development had at least 5 years of teaching experience and only taught middle school students.

\subsection{Data Collection and Analysis}

I used two methods of data collection, document analysis and interviews. The document analysis focused on the syllabi used in middle schools EFL classrooms. I only discuss the syllabus of quatrième which corresponds to the $8^{\text {th }}$ grade in the U.S. Besides, I interviewed five in-service teachers, five pre-service teachers, and five teachers in professional development. The interview questions were open-ended. The data analysis procedure was inductive, that is I used content analysis to examine the data. Patton (1990) discusses content analysis as the "process of identifying, coding, and categorizing the primary patterns in the data" (p. 381). It consisted in identifying recurrent themes and sub-themes that were coded to make sense of the data.

\section{Findings}

A scrutiny of the 4eme syllabus unveils that it is a functional syllabus in that it clearly specifies the functions to be achieved throughout the units. Nunan (1988) argues that a functional syllabus includes grammatical points to be taught but also considers "items which [the designers] imagine will help the learners to carry out the communicative purposes for which [the learners] need the language" (p. 37). And those items include the function of the language, the aim of the lesson, as well as its objectives, finally the organization of the syllabus around units. In the table below is an example of how the syllabus is organized per unit.

Table 1. Extract of syllabus as organized by unit

\begin{tabular}{|c|c|c|c|c|c|c|}
\hline Unit & Lesson & Aim & Objectives & Functions & Structures/Lexis & Skills \\
\hline $\begin{array}{l}\text { Information and } \\
\text { Communication } \\
\text { Technologies }\end{array}$ & The Internet & $\begin{array}{l}\text { To expand the } \\
\text { pupils' } \\
\text { knowledge of } \\
\text { the Internet }\end{array}$ & $\begin{array}{l}\text { The pupils will be able } \\
\text { to: } \\
\text { - say what the Internet } \\
\text { is } \\
\text { - identify the conditions } \\
\text { for connecting to the } \\
\text { Internet }\end{array}$ & $\begin{array}{l}\text { Defining } \\
\text { Identifying }\end{array}$ & $\begin{array}{l}\text { - Past perfect } \\
\text { - If clause } \\
\text { (type 1) } \\
\text { - Passive }\end{array}$ & $\begin{array}{l}\text { - Reading } \\
\text { - Speaking } \\
\text { - Writing } \\
\text { - Listening }\end{array}$ \\
\hline
\end{tabular}

As one can notice, it is organized around units which are divided into lessons. For each lesson, the designers provided the aim, the objectives, the functions, the structures/lexis, and the skills. Put together, each of those items is expected to be a significant tool that would be used by teachers to help their students develop communicative competence according to teacher supervisors. The teacher supervisors who participated in this study unanimously concurred that the identification of functions is meant to facilitate the achievement of communicative competence.

Beside the identification of function, the syllabus of 4eme is subdivided into six units to be covered throughout the academic year. Those units are road safety, information and communication technology, population, environmental education, STDs (Sexually transmitted diseases), and civics and morals. Each unit includes two lessons at the exception of the unit on civics and morals that consists of only one lesson. Each lesson addresses a topic of social relevance referred to as 'current theme.' The 'current themes' are supposedly relevant to the students' daily realities and include a text that could be used to meet the objectives of the lesson. Below is an excerpt of the text dealing with the theme of the internet suggested by the syllabus designer.

The Internet or the World Wide Web is indeed a wonderful and amazing addition in our lives. The Internet can be known as a kind of global meeting place where people from all parts of the world can come together. It is a service available on the computer, through which everything under the sun is now at the fingertips of anyone who has access to the Internet. To get 'online', meaning to connect to the Internet, you need to have: 
- A Computer: Computer equipment is a sizeable investment and thus you should select a computer carefully. Before buying a computer, understand your needs and then choose one accordingly. See that it comes with a warranty and that after sales service is available in case you need it.

- Internet Service Provider: This is the software that you will require to get online. You can now choose from a dial-up service or 24-hour broadband services. This is the service that will help you to connect to the Internet and start your surfing experiences. From Wikipedia, the free encyclopedia (adapted).

The note addressed to teachers in the syllabus states that "the teacher may adapt the texts proposed by simplifying the vocabulary and structures, providing vocabulary, studying texts in chunks ... according to his teaching context" (p. 2). This statement, hence gives teachers some freedom in the use of the text. However, during the interviews, the teacher participants all reported a lack of flexibility in the choice of the text to use. They defend not having access to the necessary resources for adapting the text to their teaching context. Taking the example of the internet, one teacher revealed his own weakness in the sense that he had been working for more than 5 years in a remote area of the country where the computer itself is very scare let alone the internet. It was then very difficult for him to update his personal knowledge to adjust the text.

Another issue here is the relevance of some units to the local environment of the learners. All my teacher participants who worked in rural area reported never teaching the lesson on the internet because, as one of the teacher said it "if we all agree that the internet is a current theme, it is not current everywhere in the country. In some rural area like the eastern part of the country where I work, the students have never seen a computer let alone the internet." Some of the teachers also unveiled their own weaknesses when it came to the use of the internet itself. The truth is that neither of the participants in professional development or the in-service teachers was familiar to the internet prior to the beginning of their training. They all reported using the internet for the first time during this academic year. That weakness was confirmed by teacher supervisors who never observed a class dealing with the internet.

Besides, the participants raised issues relevant to their understanding of the syllabus. According to the note to teachers of the syllabus, the previous syllabus that was structure based was revised because the supervisors noticed during class visits that "most English teachers in Burkina Faso teach grammar and reading basically. [...] Yet teaching involves more than these two language aspects." The difficulty however, according to teachers is that the syllabus does not say much about the other aspects of language teaching involved with this syllabus. This concern is equally shared with teacher supervisors who regret the lack of communication between teachers and supervisors about appropriate use of this syllabus. In fact, one of them noted that most teachers use the syllabus the same way they used the previous one, mostly teaching the grammar points and reading comprehension. According to both teachers and supervisors, teachers have yet to be trained about communicative purposes of language teaching as adopted by the country before they can use the syllabus appropriately.

\section{Discussion}

The data presented in the finding sections unravels a few themes that will be addressed in this section. As it can be noted on the excerpt of the syllabus above, language learning is based on the functions identified. Throughout the lesson on the internet, the structural elements and the different skills will be used by the teachers in helping their students reach the functions mentioned. The identification of the functions is however not conducive to the development of communicative competence for a few reasons.

The first one being teachers' unawareness of the goal of the new syllabus and its use. That unawareness could be attributed to some of the limitations of the functional syllabus which Hasan (2007) reports, deals with "items" not "strategies", 'components of discourse' not "process of its creation"” (p. 52). Hence, the syllabus points out items to be taught for the identified functions. Unfortunately, since most teachers have never heard of CLT or don't even have any basic information about the organization of the new syllabus, teachers mostly use it as a structural syllabus. Besides, the syllabus shows a set of elements that needs to be mastered by students. It does not necessarily show them how to put those isolated knowledge together to achieve communicative competence. As a matter of fact, in the example of the lesson on the internet, there is a list of grammatical points to be addressed in the unit and a text to be studied. However, it can be noticed that the text and the grammatical elements to be addressed are isolated. There is no reference of either one of the grammatical elements in the text. That then assumes that teachers will most likely teach the past tense, the 'if clause' and the passive voice as separate units and students in turn will master the forms that "they are unable to put together for communication" (Hadley, 1998, p. 58).

Another issue here is a lack of collaboration and communication between teachers and their supervisors. It is to be noted that the new syllabus was elaborated for the most part by teacher supervisors. Unfortunately, despite the 
major role they played in designing the syllabus, there is no communication between them and the teachers who are the ones in charge of materializing the syllabus in the classrooms. In fact, Savignon (2002) argues that "program design and implementation depend on negotiations between policy makers, linguists, researchers, and teachers" (p. 4). Teachers' apparent ignorance of CLT and the purpose of the new syllabus hence betray the lack of negotiation between the different parties and affect the successful use of the syllabus to achieve communicative competence.

Besides, there seems to be another difficulty related to the homogenization of topics. According to Savignon (2002), the achievement of communicative competence involves the identification of learners' communicative needs which will in turn be used as a basis for syllabus design. She writes that "Learners' communicative needs provide a framework for elaborating program goals regarding functional competence" (p. 4). Canale and Swain (1980) also insisted on the importance of basing the communicative syllabus on the "varieties of second language that learner is most likely to be in contact with in a genuine communicative situation" (p. 27). Through an examination of the "current themes" available in the syllabus, it is normal to wonder whose communicative needs are concerned. If themes like deforestation, pollution, rural exodus are very important and need to be addressed in class, they are not necessarily themes that students are eager to talk about. Besides, in the context of Burkina Faso, a theme like the internet is very much necessary and current in middle class families where children are exposed to it. When it comes to rural areas and low-income families, however, the internet is a foreign concept.

Another point to consider in this discussion is material development. A significant issue with the implementation of the new syllabus is the lack of adapted material. The textbooks used in the classrooms are relevant with the structural syllabi previously used in the school system. Although the new syllabus identifies grammatical points that are consistent with the textbooks, the "current themes" noted in the syllabus are irrelevant. The irrelevance of the new syllabus with the textbooks in use in the classrooms hinders the possibility of developing communicative competence. In fact, as it was pointed out by Richard (2006), material development should be applied "to syllabus design issues and as a source for instructional principles that can inform the design of instructional materials" ( $p$. 23).

\section{Conclusion}

Throughout this article, I have argued that despite the introduction of new syllabi that would facilitate the implementation of communicative language teaching, EFL is still struggling to help students develop communicative competence in Burkina Faso. The difficulties experienced in the field of English language teaching reside among other things in the lack of collaboration between teachers, teacher supervisors, and policy makers and the limited knowledge of teachers on communicative language teaching. The lack of collaboration between the different parties and the ignorance of teachers affect the quality of the new syllabi, the extent to which they are used effectively in the classroom, and the ability of students to learn English for communicative purposes. The result is hence an unawareness of teaching approaches and techniques, the non-adaptation of the new syllabus to the actual needs of the learners, and the lack of coordination between the syllabi and the textbooks in use in the classroom. These points weaken the English language teaching program in the country and jeopardize the goal of the language teaching that is communicative competence.

\section{References}

Bourke, J. M. (2006). Designing a topic-based syllabus for young learners. ELT Journal, 60, 279-286. https://doi.org/10.1093/elt/ccl008

Canale, M., \& Swain, M. (1980). Theoretical bases for communicative approaches to second language teaching and testing. Applied Linguistics, 1, 1-47. https://doi.org/10.1093/applin/1.1.1

Ceke-Murcia, M., Dornyei, Z., \& Thurrell, S. (1995). Communicative Competence: A Pedagogically Motivated Model with Content Specifications. Issues in Applied Linguistics, 6, 5-35.

Ellis, R. (1993). The structural syllabus and second language acquisition. TESOL Quarterly, 27, 991-113. https://doi.org/10.2307/3586953

Hadley, G. (1998). Returning full circle: A survey of EFL syllabus designs for the new millennium. RELC Journal, 29, 50-71. https://doi.org/10.1177/003368829802900203

Hasan, A. S. (2007). The Envisaged Syllabus for Teaching English as a Foreign Language. Damascus University Journal, 23, 45-61.

Hymes, D. H. (1972) 'Models of the interaction of language and social life', In J. J. Gumperz, \& D. Hymes (Eds.), Directions in sociolinguistics: The ethnography of communication (pp. 35-71). New York: Holt, Rinehart \& 
Winston.

Kramsch, C. (2006). From communicative competence to symbolic competence. The Modern Language Journal, 90, 249-252. https://doi.org/10.1111/j.1540-4781.2006.00395_3.x

Littlewood, W. (1982). Communicative language teaching. Cambridge University Press.

Nunan, D. (1988). Syllabus design. Oxford: Oxford University Press.

Patton, M. Q. (1990). Qualitative evaluation and research methods. New York, NY: Sage Publications.

Rahimpour, M. (2010). Current trends on syllabus design in foreign language instruction. Procedia Social and Behavioral Sciences, 2, 1660-1664. https://doi.org/10.1016/j.sbspro.2010.03.254

Richard, J. C. (2006). Communicative language teaching today. New York: Cambridge University Press.

Richard, J. C. (2006). Material development and research: Making the connection. RELC Journal, $37,5-26$. https://doi.org/10.1177/0033688206063470

Richard, J. C. (2013). Curriculum approaches in language teaching: Forward, central, and backward design. RELC Journal, 44, 5-44. https://doi.org/10.1177/0033688212473293

Savignon, S. J. (2002). Communicative language teaching: Linguistic theory and classroom practice, In S. S. Savignon (Ed.), Interpreting communicative language teaching: Contexts and concerns in teacher education (pp. 1-27). Yale University press.

Yalden, J. (1984). Syllabus design in general education: Options for ELT. In C. J. Brumfit (Eds.), General English syllabus design (pp. 13-22). Oxford: Pergamon press.

\section{Copyrights}

Copyright for this article is retained by the author(s), with first publication rights granted to the journal.

This is an open-access article distributed under the terms and conditions of the Creative Commons Attribution license (http://creativecommons.org/licenses/by/4.0/). 